\section{Simulated Seawater Flooding Reduces the Growth of Ten Vegetables}

\author{
Youping Sun \\ Texas A\&M AgriLife Research and Extension Center at El Paso, Texas A\&M \\ University System, 1380 A\&M Circle, El Paso, TX 79927
}

Joseph Masabni

Texas A\&M AgriLife Extension, Texas A\&M University, College Station, TX 77843

\section{Genhua Niu ${ }^{1}$}

Texas A\&M AgriLife Research and Extension Center at El Paso, Texas A\&M University System, 1380 A\&M Circle, El Paso, TX 79927

Additional index words. mineral nutrition, photosynthetic rate, salt tolerance, SPAD

\begin{abstract}
Excessive salinity in soil and irrigation water in combination with waterlogging in coastal regions can significantly reduce the productivity of many agricultural crops. To evaluate the plant growth responses to simulated seawater (SSW) flooding, seedlings of 10 vegetables (broccoli, chinese cabbage, chinese greens, cucumber, eggplant, kale, radish, 'Red Crunchy' radish, spinach, and tomato) were flooded with SSW at electrical conductivity (EC) of $44.0 \pm 1.3 \mathrm{dS} \cdot \mathrm{m}^{-1}$ or tap water at EC of $0.8 \pm 0.1 \mathrm{dS} \cdot \mathrm{m}^{-1}$ for 24 hours and grown subsequently for 2 weeks in a greenhouse. Chinese greens and cucumber plants died shortly after flooding with SSW, whereas other vegetables exhibited various degrees of visible salt damage. Chinese cabbage suffered the strongest reduction, whereas spinach, tomato, and eggplant exhibited the least decrease in dry weight (DW) due to SSW flooding in comparison with their perspective control. Two weeks after flooding treatment with SSW, net photosynthetic rate of broccoli, kale, spinach, and tomato was reduced by $43 \%$ to $67 \%$, transpiration rate by $35 \%$ to $66 \%$, and stomatal conductance $\left(g_{S}\right)$ by $51 \%$ to $82 \%$. In summary, spinach, eggplant, and tomato were the most tolerant, whereas chinese cabbage, chinese greens, and cucumber were the least tolerant to SSW flooding.
\end{abstract}

Crop production in coastal areas is threatened by seawater intrusion, which increases soil salinity. Seawater intrusion will become a more prominent concern as sea level continues to rise with global climate change and overuse of groundwater. According to Stoner (1988), about 40,000 ha of arable lands are lost every year due to salinity and waterlogging. Excessive salinity in soil and irrigation water in combination with waterlogging can significantly reduce the productivity of many agricultural crops, especially those vegetables that are sensitive to salinity.

Salinity is one of the major abiotic stresses that threaten agricultural production. Increasing salinity in soil and irrigation water usually leads to a buildup in sodium $(\mathrm{Na})$ and chloride (Cl) content and imposes water deficit detrimental to plants (Yamaguchi and Blumwald, 2005). Adverse effects associated with salinity include plant growth reduction, leaf burning, decreased photosynthesis, and potentially death (Munns and Tester, 2008). Salt tolerance

Received for publication 14 Jan. 2015. Accepted for publication 9 Mar. 2015.

This work was supported by the USDA National Institute of Food and Agriculture, Hatch Project TEX090450, and Texas A\&M AgriLife Research. ${ }^{1}$ To whom reprint requests should be addressed; e-mail gniu@ag.tamu.edu.

more sensitive to salinity during germination and early growth, but moderately to highly salt tolerant at maturity (Ungar, 1996). The response of eggplant cultivars Kemer, Pala, and Aydin Siyahi to salinity varied also with plant growth stage with salt tolerance increasing as later growth stages progressed (Akinci et al., 2004).

Flooding is another major abiotic stress significantly impacting crop growth and productivity. An estimated $\$ 500-\$ 600$ million in agricultural production was lost due to flooding in eastern Australia in 2010-11, especially the production of cotton, fruit, grain sorghum, vegetables, and winter crops (ABARES, 2011). In general, flooding damages vegetables by reducing oxygen in the root zone, which inhibits aerobic processes. Flooding restricts respiration and gaseous exchange, ceases growth processes, reduces yields, or even leads to death and decay of crop plants (Visser et al., 2003). Johnson (2011) reported that most vegetable crops can recover if the flooding or waterlogging duration is less than $48 \mathrm{~h}$. Longer flood periods will lead to root death and lower chances of recovery. Most vegetables are highly sensitive to flooding and genetic variation is high. Tomato 'LA1579' genotype is flooding sensitive, whereas genotype 'CLN2498E' and 'CA4' show high tolerance to flooding (Ezin et al., 2010).

Some plants have developed a mechanism that allows them to exclude salts from their shoots or tolerate accumulated salts in their tissue (Munns and Tester, 2008). However, the mechanism to exclude salts from shoots will break down and roots become "leaky" to salts because waterlogging makes plant roots oxygen deficient and thus decreases their production of energy (Qureshi and BarrettLennard, 1998). Barrett-Lennard (1986) observed that waterlogging and salinity interactively allow large and rapid accumulation of $\mathrm{Na}$ and $\mathrm{Cl}$ in plant shoots. $\mathrm{Na}$ content in wheat leaves continuously increased with salt and waterlogged treatment (Ibrahim et al., 2007).

Salt-waterlogged treatment also greatly reduced grain DW and number per plant in Triticum aestivum (wheat) 'Pirsabak', 'Inqlab91', 'SARC-6', and 'HD-2320' (Ibrahim et al., 2007). In addition, there is substantial evidence that waterlogging under salt conditions increases leaf senescence. The combination of waterlogging and salinity $\left(8.7 \mathrm{dS} \cdot \mathrm{m}^{-1} \mathrm{NaCl}\right)$ increased the numbers of senescenced leaves, but did not affect the rate of production of new leaves of squash (Cucurbita pepo) that grew in sand irrigation (Huang et al., 1995a, 1995b).

Little information is available on the tolerance of many vegetables at early stages of development to seawater flooding. The purpose of this study was to evaluate the plant growth responses of 10 common vegetable crops to SSW flooding for $24 \mathrm{~h}$ in a greenhouse. Gas exchange rates and leaf $\mathrm{Na}$, potassium $(\mathrm{K})$, calcium $(\mathrm{Ca})$, and $\mathrm{Cl}$ accumulation of selected vegetables were also determined.

\section{Materials and Methods}

Plant materials. On 8 Jan. 2014, seeds of 10 vegetables [eggplant 'Amadeo' hybrid (Solanum melongena), broccoli 'Packman' hybrid (Brassica oleracea), kale 'Winterbor' hybrid (Brassica oleracea), chinese cabbage 'Kaboko' (Brassica campestris), tomato 'Mega Bite' hybrid (Solanum lycopersicum), spinach 'Palco' hybrid (Spinacia oleracea), cucumber 'Spring Swallow' hybrid (Cucumis sativus), radish (Raphanus sativus) (Geo. W. Park Seed Co., Inc., Greenwood, SC), radish 'Red Crunchy' hybrid (Abbott \& Cobb, Inc., Feasterville, PA), chinese greens (Brassica rapa; Seedway, Inc., Hall, NY)] were sown at a depth of $0.5 \mathrm{~cm}$ in a germination insert $(13.5 \mathrm{~cm} \times 13.5 \mathrm{~cm} \times 4.5 \mathrm{~cm})$ filled with Metro-Mix 360 (Sun Gro Horticulture, Bellevue, WA). Flats were placed under intermittent mist with reverse osmosis (RO) water and the misting frequency was controlled by a timer (Phytotronics Inc., Earthcity, MO) set at $20 \mathrm{~s}$ 
per hour. One week later, seedlings emerged, and they were moved out of the mist bench and placed on greenhouse bench. Seedlings were watered with nutrient solution with an EC of $1.6 \pm 0.3 \mathrm{dS} \cdot \mathrm{m}^{-1}$. The nutrient solution was prepared by adding $0.72 \mathrm{~g} \cdot \mathrm{L}^{-1} 15 \mathrm{~N}-2.2 \mathrm{P}-$ 12.5 K (Peters 15-5-15, Marysville, $\mathrm{OH}$ ) to tap water. On 21 Jan., seedlings were transplanted into 4 -inch pots $(8.5 \mathrm{~cm} \times 8.5 \mathrm{~cm} \times 8.0 \mathrm{~cm})$, one plant per pot, filled with Metro-Mix 360 and were watered with nutrient solution until treatments were initiated.

Treatments. On 6 Feb., 4 weeks after sowing, flats with 10 vegetable species were placed (flooded) in a tub for $24 \mathrm{~h}$ with SSW or with tap water (tap water flooding control). There were 12 seedlings per species, 12 plants per flat, 30 flats in total. The EC for SSW and tap water was $44.0 \pm 1.3 \mathrm{dS} \cdot \mathrm{m}^{-1}$ and $0.8 \pm 0.1 \mathrm{dS} \cdot \mathrm{m}^{-1}$, respectively. The flooding completely immersed the growing medium but leaves were not in contact with SSW or tap water. Another group of seedlings were not immersed and served as no flooding control. The SSW was prepared by adding $35 \mathrm{~g}$ of $\mathrm{NaCl}$ (Fisher Scientific, Waltham, MA) to $1 \mathrm{~kg}$ of tap water (Wikipedia, The Free Encyclopedia, 2014). All flooded seedlings were moved out of the tub $24 \mathrm{~h}$ later. The substrate EC was determined by using pour-through protocol (Cavins et al., 2008) and measured using an EC meter (Model B173; Horiba, Ltd., Japan). The substrate EC was $4.1 \pm 1.1 \mathrm{dS} \cdot \mathrm{m}^{-1}, 2.5 \pm 0.5 \mathrm{dS} \cdot \mathrm{m}^{-1}$, and $43.0 \pm 4.7 \mathrm{dS} \cdot \mathrm{m}^{-1}$ for control without flooding, tap water flooding, and SSW flooding, respectively, measured the day after SSW treatment. All seedlings were placed on greenhouse benches and grown subsequently for another 2 weeks. Plants were irrigated with nutrient solution whenever the substrate surface started to dry (a total of three times during the 2-week period). Temperature in the greenhouse was maintained at $25.7 \pm 8.1{ }^{\circ} \mathrm{C}$ during the day and $13.4 \pm 4.5^{\circ} \mathrm{C}$ at night. The daily light integral photosynthetically active radiation $(P A R)$ was $12.3 \pm 2.2 \mathrm{~mol} \cdot \mathrm{m}^{-2} \cdot \mathrm{d}^{-1}$. The substrate final ECs, determined using saturated paste extract (Gavlak et al., 1994; USDA Staff, 1954), were $3.1 \pm 0.2 \mathrm{dS} \cdot \mathrm{m}^{-1}$, $2.4 \pm 0.2 \mathrm{dS} \cdot \mathrm{m}^{-1}$, and $7.3 \pm 0.7 \mathrm{dS} \cdot \mathrm{m}^{-1}$, respectively, for control without flooding, tap water flooding, and SSW flooding.

Growth data. At the end of the experiment (2 weeks after flooding treatment), visual foliar salt damage of every plant (leaf edge burn, necrosis, or discoloration) was rated on a score of 0 to 5 , where $0=$ dead, $1=$ severe (over $90 \%), 2=$ moderate $(50 \%$ to $90 \%), 3=$ slight $(<50 \%), 4=$ good quality with minimal foliar damage, and $5=$ excellent with no visible foliar damage. Plant height was recorded from the pot rim to the top growth point, or leaf apex of the longest leaf. The shoots of all plants were severed at the substrate surface, and fresh weight was recorded immediately. Leaf area of all plants was determined using LI-3100C area meter (LI-COR ${ }^{\circledR}$ Biosciences, Lincoln, NE). Shoot DW was determined after shoots were ovendried at $65{ }^{\circ} \mathrm{C}$ to constant weight.
Gas exchange and SPAD reading. Gas exchange and relative chlorophyll content were measured for broccoli 'Packman' hybrid, eggplant 'Amadeo' hydrid, kale 'Winterbor' hybrid, spinach 'Palco' hybrid, and tomato 'Mega Bite' hybrid. Gas exchange and relative chlorophyll content were not measured for other species because the plants were dead or almost dead by the end of the experiment. Leaf net photosynthesis $\left(\mathrm{P}_{\mathrm{n}}\right)$, transpiration $(\mathrm{E})$, and $g_{\mathrm{S}}$ of five plants per species per treatment were measured $1 \mathrm{~d}$ before growth data were taken using a CIRAS-2 portable photosynthesis system (PP Systems, Amesbury, MA) with an automatic universal PLC6 broad leaf cuvette. Fully expanded healthy leaves were chosen for measurements. The environmental conditions in the cuvette were set at leaf temperature of $25^{\circ} \mathrm{C}$, photosynthetic photon flux $(P P F)$ of $1000 \mu \mathrm{mol} \cdot \mathrm{m}^{-2} \cdot \mathrm{s}^{-1}$, and $\mathrm{CO}_{2}$ concentration of $375 \mu \mathrm{mol} \cdot \mathrm{mol}^{-1}$. Data were recorded when the environmental conditions and gas exchange parameters in the cuvette became stable. These measurements were taken on a sunny day between 10:00 AM and 2:00 PM, and the plants were well watered to avoid water stress.

Leaf greenness or relative chlorophyll content of five plants per species per treatment was measured using a handheld SPAD chlorophyll meter (Minolta Camera Co., Osaka, Japan) $1 \mathrm{~d}$ before harvest. For each plant, five healthy and fully expanded leaves were chosen for measuring the relative chlorophyll content (SPAD) readings.

Ion analysis. Five leaf samples per treatment per species were randomly selected for mineral analysis. Plants in the control treatment and SSW flooding treatment were chosen for mineral analysis. Dried tissue samples were ground to pass a 40-mesh screen with a stainless Wiley mill (Thomas Scientific, Swedesboro, NJ). Plant tissues were digested using environmental protection agency method 3051 with $1 \mathrm{~mL}$ nitric acid and $4 \mathrm{~mL}$ hydrogen peroxide using a microwave acceleration reaction system (CEM Corporation; Mathews, NC) for determining alkaline earth metals ( $\mathrm{Na}, \mathrm{K}, \mathrm{Ca})$. The plant tissues were extracted with $2 \%$ acetic acid (EM Science, Gibbstown, NJ) for determining anions $(\mathrm{Cl})$ using methods described by Gavlak et al. (1994). Na, K, and Ca in the digested samples were analyzed by inductively coupled plasma-optical emission spectrometry (Perkin-Elmer Optima 4300 DV; Perkin-Elmer, Shelton, CT). Cl was determined by M926 Chloride Analyser (Cole Parmer Instrument Company, Vernon Hills, IL).

Experimental design and statistical analysis. The experiment followed a splitplot design with flood treatment as the main plot and species as subplot with 12 replications. All data were analyzed as a two-way analysis of variance (ANOVA) using PROC GLM. Because all growth, gas exchange, and mineral element data of plants in the control treatment were not significantly different from those of plants flooded with tap water, they were pooled for further analysis. For each species, Student's $t$ tests between treatments were conducted within species. Relative height for each plant in the SSW treatment was calculated as follows:

$$
\begin{aligned}
\text { Relative height }(\%)= & \frac{\text { Height in SSW treatment }}{\text { Averaged height in control }} \\
& \times 100 \%
\end{aligned}
$$

Similarly, relative percent for leaf count, leaf area, fresh weight, DW, and gas exchange, SPAD were calculated. Relative reduction values were also used for ANOVA analysis. Mean separation among species were conducted using Tukey's honest significant difference. All statistical analyses were performed using SAS (Version 9.1.3; SAS Institute Inc., Cary, NC).

\section{Results and Discussion}

Plant growth. As mentioned earlier, data from the tap water flooding control and the control without flooding were pooled in data analysis because no statistical differences in growth or physiological parameters were found between these two control groups. In other words, the 24-h flooding with tap water did not have a negative impact on the growth of vegetables in the subsequent 2 weeks. Therefore, results of SSW treatment were compared with those of the pooled control.

There were interactions between treatment and vegetable type for plant height, leaf count, leaf area, fresh weight, DW, and visual score $(P<0.0001)$. Chinese greens and cucumber flooded with SSW died at the end of experiment or 2 weeks after flooding. Therefore, their growth data were not collected. Visual scores of all plants flooded with SSW were significantly lower than those in the control treatment (Table 1). Broccoli, kale, and tomato plants flooded with SSW had minimal foliar damage with visual score of 4.8, 4.6, and 4.0, respectively. Eggplant

Table 1. Effect of flooding with simulated seawater (SSW) on the growth of 10 vegetables. Visual foliar salt damage of every plant (leaf edge burn, necrosis, or discoloration) was rated at the end of experiment on a score of 0 to 5 where $0=$ dead; $1=$ severe $($ over $90 \%) ; 2=$ moderate $(50 \%$ to $90 \%) ; 3=$ slight $(<50 \%) ; 4=\operatorname{good}$ quality with minimal foliar damage; and $5=$ excellent with no visible foliar damage.

\begin{tabular}{lcc}
\hline & \multicolumn{2}{c}{ Visual score } \\
\cline { 2 - 3 } Species & Control & SSW \\
\hline Broccoli & $5 \mathrm{a} \mathrm{A}$ & $4.8 \mathrm{~b}^{\mathrm{z}} \mathrm{A}^{\mathrm{y}}$ \\
Chinese cabbage & $5 \mathrm{a} \mathrm{A}$ & $1.8 \mathrm{~b} \mathrm{CD}$ \\
Chinese greens & $5 \mathrm{a} \mathrm{A}$ & $0.0 \mathrm{~b} \mathrm{E}$ \\
Cucumber & $5 \mathrm{a} \mathrm{A}$ & $0.0 \mathrm{~b} \mathrm{E}$ \\
Eggplant & $5 \mathrm{a} \mathrm{A}$ & $3.9 \mathrm{~b} \mathrm{~A}$ \\
Kale & $5 \mathrm{a} \mathrm{A}$ & $4.6 \mathrm{~b} \mathrm{~A}$ \\
Radish & $5 \mathrm{a} \mathrm{A}$ & $2.2 \mathrm{~b} \mathrm{BC}$ \\
'Red Crunchy' radish & $5 \mathrm{a} \mathrm{A}$ & $0.6 \mathrm{~b} \mathrm{DE}$ \\
Spinach & $5 \mathrm{a} \mathrm{A}$ & $3.5 \mathrm{~b} \mathrm{AB}$ \\
Tomato & $5 \mathrm{a} \mathrm{A}$ & $4.0 \mathrm{~b} \mathrm{~A}$ \\
\hline
\end{tabular}

${ }^{\mathrm{z}}$ For each species, means with same lowercase letters are not significantly different between treatments by Students' $t$ test at $P<0.05$.

${ }^{\mathrm{y}}$ Means with same uppercase letters within column are not significantly different among vegetables by Tukey's honest significant difference test at $P<0.05$. 
Table 2. Effect of flooding with simulated seawater (SSW) on the growth of 10 vegetables. Height, leaf count, and leaf area were recorded at the end of experiment. Relative reduction (\%) in height, leaf count, and leaf area were calculated as percent of control.

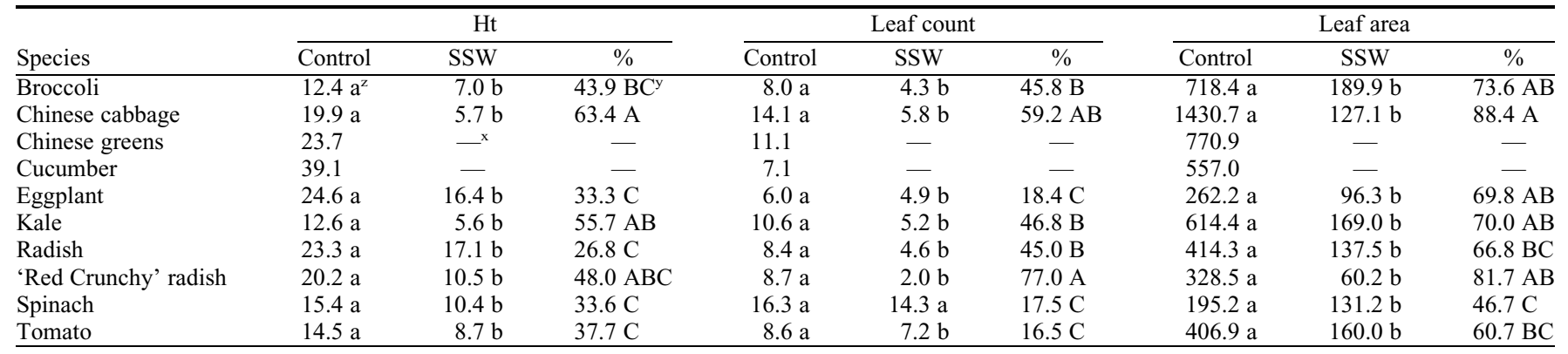

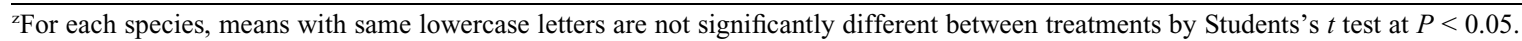

${ }^{y}$ Means with same uppercase letters within column are not significantly different among vegetables by Tukey's honest significant difference test at $P<0.05$.

${ }^{x}$ Data were not collected due to plant death.

Table 3. Effect of flooding with simulated seawater (SSW) on the growth of 10 vegetables. Fresh weight $(\mathrm{g})$ and dry weight $(\mathrm{g})$ were recorded at the end of experiment. Relative reduction $(\%)$ in fresh weight and dry weight were calculated as percent of control.

\begin{tabular}{|c|c|c|c|c|c|c|}
\hline \multirow[b]{2}{*}{ Species } & \multicolumn{3}{|c|}{ Fresh wt } & \multicolumn{3}{|c|}{ Dry wt } \\
\hline & Control & SSW & $\%$ & Control & SSW & $\%$ \\
\hline Broccoli & $50.2 \mathrm{a}^{\mathrm{z}}$ & $15.3 \mathrm{~b}$ & $69.6 \mathrm{BCD}^{\mathrm{y}}$ & $4.7 \mathrm{a}$ & $1.6 \mathrm{~b}$ & $66.5 \mathrm{AB}$ \\
\hline Chinese cabbage & $93.6 \mathrm{a}$ & $9.5 \mathrm{~b}$ & $87.2 \mathrm{~A}$ & $7.5 \mathrm{a}$ & $2.0 \mathrm{~b}$ & $72.9 \mathrm{~A}$ \\
\hline Chinese greens & 92.5 & $-^{x}$ & - & - & - & - \\
\hline Cucumber & 30.6 & - & - & - & - & - \\
\hline Eggplant & $15.6 \mathrm{a}$ & $6.7 \mathrm{~b}$ & $53.8 \mathrm{DE}$ & $1.6 \mathrm{a}$ & $0.7 \mathrm{~b}$ & $60.9 \mathrm{ABC}$ \\
\hline Kale & $45.2 \mathrm{a}$ & $13.2 \mathrm{~b}$ & $68.2 \mathrm{BCD}$ & $4.6 \mathrm{a}$ & $1.5 \mathrm{~b}$ & $66.5 \mathrm{AB}$ \\
\hline Radish & $66.4 \mathrm{a}$ & $18.2 \mathrm{~b}$ & $72.6 \mathrm{ABC}$ & $4.9 \mathrm{a}$ & $1.7 \mathrm{~b}$ & $69.4 \mathrm{AB}$ \\
\hline 'Red Crunchy' radish & $66.2 \mathrm{a}$ & $12.3 \mathrm{~b}$ & $81.5 \mathrm{AB}$ & $4.3 \mathrm{a}$ & $1.5 \mathrm{~b}$ & $65.7 \mathrm{AB}$ \\
\hline Spinach & $20.1 \mathrm{a}$ & $10.7 \mathrm{~b}$ & $40.5 \mathrm{D}$ & $2.3 \mathrm{a}$ & $1.2 \mathrm{~b}$ & $48.3 \mathrm{C}$ \\
\hline Tomato & $25.5 \mathrm{a}$ & $9.6 \mathrm{~b}$ & $59.6 \mathrm{CD}$ & $2.2 \mathrm{a}$ & $0.9 \mathrm{~b}$ & $55.0 \mathrm{BC}$ \\
\hline
\end{tabular}

${ }^{\mathrm{z}}$ For each species, means with same lowercase letters are not significantly different between treatments by Students's $t$ test at $P<0.05$.

${ }^{\mathrm{y}}$ Means with same uppercase letters within column are not significantly different among vegetables by Tukey's honest significant difference test at $P<0.05$.

${ }^{x}$ Data were not collected due to plant death.

and spinach plants had slight foliar damage with visual scores of 3.9 and 3.5 , respectively. Radish and chinese cabbage plants had moderate foliar damage with visual score of 2.2 and 1.8, respectively, whereas 'Red Crunchy' radish exhibited over $90 \%$ foliar damage with visual score of 0.6.

Plants flooded with SSW were shorter than those in the control treatment (Table 2). Compared with the control plants, the height of chinese cabbage and kale plants flooded with SSW was reduced by $63.4 \%$ and $55.7 \%$, respectively, whereas that of eggplant, radish, spinach, and tomato plants decreased by $26.8 \%$ to $37.7 \%$. All vegetables except spinach flooded with SSW had reduced number of leaves than those in the control treatment. The number of leaves in 'Red Crunchy' radish and chinese cabbage plants were reduced by $77.0 \%$ and $59.2 \%$, respectively. The relative reductions in number of leaves for eggplant, spinach, and tomato plants flooded with SSW were $16.5 \%$ to $18.4 \%$, whereas those of broccoli, kale, and radish were $45.0 \%$ to $46.8 \%$. Plants flooded with SSW had smaller leaf area than those in the control treatment (Table 2). Compared with plants in the control treatment, leaf area of chinese cabbage plants reduced the most $(88.4 \%)$, whereas that of spinach plants decreased the least $(46.7 \%)$. Other vegetables had $60.7 \%$ to $81.7 \%$ smaller leaf area than those in the control treatment. Foliar damage and reduced leaf number and area are undesirable for the production and marketability of leafy vegetables such as chinese cabbage, kale, and spinach. The reduction in leaf number and area would reduce the assimilation of carbohydrates, resulting in poorer quality of vegetables.

Salinity and waterlogging negatively impact the productivity of many agricultural crops (Visser et al., 2003). Plants flooded with SSW produced less fresh and DW compared with those in the control (Table 3). All tested vegetables had $40.5 \%$ to $87.2 \%$ loss in fresh weight and $48.3 \%$ to $77.7 \%$ loss in DW. Chinese greens and cucumber plants died when they were flooded with SSW. Chinese cabbage had a loss of $87.2 \%$ in fresh weight and $72.9 \%$ in DW. These results indicate that chinese cabbage, chinese greens, and cucumber are very sensitive to SSW flooding. In a previous report, chinese cabbage was placed in the moderately salt sensitive category based on the fact that the yield of mature plants was reduced about $10 \%$ per $\mathrm{dS} \cdot \mathrm{m}^{-1}$ (Maas, 1986). The different growth stages of chinese cabbage plants may attribute to the discrepancy as plant salt tolerance is dependent on growth stages (Akinci et al., 2004; Chartzoulakis and Klapaki, 2000). Spinach, eggplant, and tomato had the least reduction in fresh weight $(40.5 \%$ to $59.6 \%$ ) and DW (48.3\% to $60.9 \%$ ), suggesting they were more tolerant than other tested vegetables to SSW flooding. In previous reports, eggplant and tomato were considered to be sensitive to moderately sensitive vegetables with $50 \%$ yield loss of eggplant at $8.5 \mathrm{dS} \cdot \mathrm{m}^{-1}$ soil salinity (Savvas and Lenz, 1996; Shalhevet et al., 1983) and $50 \%$ yield loss of tomato at salinity level of $5.0 \mathrm{dS} \cdot \mathrm{m}^{-1}$ (Ciobanu and Sumalan, 2009). For fruit crops like eggplant, salt tolerance in vegetative and reproductive stages could differ significantly. Ünlükara et al. (2010) reported that threshold salinity levels were 1.5 and $6.7 \mathrm{dS} \mathrm{m}^{-1}$ for fruit and vegetative growth, indicating that fruit yield is more sensitive to salinity than vegetative growth in eggplant. Spinach is a moderately salt sensitive leaf vegetable with a tolerance threshold EC of $2.0 \mathrm{dS} \cdot \mathrm{m}^{-1}$ (Shannon and Grieve, 1999). The fresh weight and DW of broccoli, kale, radish, and 'Red Crunchy' radish were decreased by $68.2 \%$ to $81.5 \%$ and $65.7 \%$ to $69.4 \%$, respectively. These data indicated that they were moderately tolerant to SSW flooding among tested vegetables. Radish is a salt sensitive crop. Root yield of radish declined $13 \%$ per $\mathrm{dS} \cdot \mathrm{m}^{-1}$ when salinity exceeded a threshold of $1.3 \mathrm{dS} \cdot \mathrm{m}^{-1}$ (Shannon and Grieve, 1999). Earlier studies indicated that broccoli is a moderately salt sensitive crop with a calculated threshold EC of the saturated paste of $2.8 \mathrm{dS} \cdot \mathrm{m}^{-1}$ (Bernstein et al., 1974; Shannon and Grieve, 1999). However, López-Berenguer et al. (2008) observed that broccoli was moderately tolerant to salinity. The discrepancy is probably due to the different criteria of classification.

Gas exchange and SPAD. Interactions between treatment and type of vegetables on $\mathrm{P}_{\mathrm{n}}, \mathrm{E}, g_{\mathrm{S}}$, and SPAD were significant, indicating different responses to SSW flooding among types of vegetables $(P<0.001)$. Flooding with SSW significantly decreased $\mathrm{P}_{\mathrm{n}}, \mathrm{E}$, and $g_{\mathrm{S}}$ of broccoli, kale, spinach, and tomato plants, but not eggplant (Table 4). The $\mathrm{P}_{\mathrm{n}}$ values of broccoli, kale, spinach, and tomato plants flooded with SSW were reduced by $42.8 \%, 42.5 \%, 67.3 \%$, and $45.6 \%$ than the control, respectively. The transpiration rates of broccoli, kale, spinach, and tomato plants flooded with SSW were 
Table 4. Effect of flooding with simulated seawater (SSW) on the leaf net photosynthesis $\left(\mathrm{P}_{\mathrm{n}}\right)$, transpiration $(\mathrm{E})$, stomatal conductance $\left(g_{\mathrm{S}}\right)$, and relative chlorophyll content (SPAD) of five vegetables. Relative reduction (\%) in $\mathrm{P}_{\mathrm{n}}, \mathrm{E}, \mathrm{g}_{\mathrm{S}}$, SPAD were calculated as percent of control. Chinese cabbage, chinese greens, cucumber, radish, and 'Red Crunchy' radish plants were not measured due to plant death or unhealthy.

\begin{tabular}{|c|c|c|c|c|c|c|c|c|c|c|c|c|}
\hline \multirow[b]{2}{*}{ Species } & \multicolumn{3}{|c|}{$P_{n}$} & \multicolumn{3}{|c|}{$\mathrm{E}$} & \multicolumn{3}{|c|}{$g_{\mathrm{S}}$} & \multicolumn{3}{|c|}{ SPAD } \\
\hline & Control & SSW & $\%$ & Control & SSW & $\%$ & Control & SSW & $\%$ & Control & SSW & $\%$ \\
\hline$\overline{\text { Broccoli }}$ & $12.7 \mathrm{a}^{\mathrm{z}}$ & $6.7 \mathrm{~b}$ & $42.8 \mathrm{~A}^{\mathrm{y}}$ & $941.0 \mathrm{a}$ & $299.2 \mathrm{~b}$ & $47.1 \mathrm{~A}$ & $19.8 \mathrm{a}$ & $11.3 \mathrm{~b}$ & $81.6 \mathrm{~A}$ & $58.7 \mathrm{a}$ & $50.4 \mathrm{~b}$ & $14.0 \mathrm{AB}$ \\
\hline Eggplant & $7.2 \mathrm{a}$ & $6.4 \mathrm{a}$ & $0 \mathrm{~B}$ & $367.1 \mathrm{a}$ & $280.0 \mathrm{a}$ & $11.5 \mathrm{~B}$ & $15.2 \mathrm{a}$ & $15.7 \mathrm{a}$ & $23.7 \mathrm{D}$ & $40.8 \mathrm{a}$ & $41.7 \mathrm{a}$ & $0 \mathrm{~B}$ \\
\hline Kale & $6.7 \mathrm{a}$ & $4.3 \mathrm{~b}$ & $42.5 \mathrm{~A}$ & $347.7 \mathrm{a}$ & $169.0 \mathrm{~b}$ & $35.2 \mathrm{AB}$ & $13.7 \mathrm{a}$ & $7.9 \mathrm{~b}$ & $51.4 \mathrm{C}$ & $45.9 \mathrm{a}$ & $45.2 \mathrm{a}$ & $1.4 \mathrm{AB}$ \\
\hline Spinach & $9.6 \mathrm{a}$ & $4.6 \mathrm{~b}$ & $67.3 \mathrm{~A}$ & $533.4 \mathrm{a}$ & $134.0 \mathrm{~b}$ & $65.5 \mathrm{~A}$ & $16.8 \mathrm{a}$ & $5.5 \mathrm{~b}$ & $76.8 \mathrm{AB}$ & $56.3 \mathrm{a}$ & $42.0 \mathrm{~b}$ & $19.4 \mathrm{~A}$ \\
\hline Tomato & $8.0 \mathrm{a}$ & $4.8 \mathrm{~b}$ & $45.6 \mathrm{~A}$ & $423.1 \mathrm{a}$ & $177.2 \mathrm{~b}$ & $40.3 \mathrm{AB}$ & $15.1 \mathrm{a}$ & $8.2 \mathrm{~b}$ & $58.1 \mathrm{BC}$ & $45.4 \mathrm{a}$ & $43.9 \mathrm{a}$ & $3.2 \mathrm{AB}$ \\
\hline
\end{tabular}



${ }^{y}$ Means with same uppercase letters within column are not significantly different among vegetables by Tukey's honest significant difference test at $P<0.05$.

Table 5. Effect of flooding with simulated seawater (SSW) on the leaf ion concentrations of eight vegetables. Chinese greens and cucumber were not analyzed because dry materials were not enough.

\begin{tabular}{|c|c|c|c|c|c|}
\hline \multirow[b]{2}{*}{ Species } & \multirow[b]{2}{*}{ Treatment } & \multicolumn{4}{|c|}{ Ion concn $\left(\mathrm{mg} \cdot \mathrm{g}^{-1}\right)$} \\
\hline & & $\mathrm{Na}$ & $\mathrm{K}$ & $\mathrm{Ca}$ & $\mathrm{Cl}$ \\
\hline & Control & $15.9 b^{z}$ & $33.3 \mathrm{a}$ & $21.5 \mathrm{a}$ & $15.1 \mathrm{~b}$ \\
\hline \multirow[t]{2}{*}{ Broccoli } & SSW & $56.8 \mathrm{a}$ & $25.8 \mathrm{~b}$ & $14.3 \mathrm{~b}$ & $99.4 \mathrm{a}$ \\
\hline & Control & $14.9 \mathrm{~b}$ & $54.5 \mathrm{a}$ & $16.6 \mathrm{a}$ & $28.7 \mathrm{~b}$ \\
\hline \multirow[t]{2}{*}{ Chinese cabbage } & SSW & $86.6 \mathrm{a}$ & $43.8 \mathrm{~b}$ & $18.6 \mathrm{a}$ & $127.2 \mathrm{a}$ \\
\hline & Control & $4.8 \mathrm{~b}$ & $52.1 \mathrm{a}$ & $9.9 \mathrm{a}$ & $10.7 \mathrm{~b}$ \\
\hline \multirow[t]{2}{*}{ Eggplant } & SSW & $27.4 \mathrm{a}$ & $35.6 \mathrm{~b}$ & $8.8 \mathrm{a}$ & $60.0 \mathrm{a}$ \\
\hline & Control & $12.0 \mathrm{~b}$ & $34.3 \mathrm{a}$ & $18.4 \mathrm{a}$ & $19.6 \mathrm{~b}$ \\
\hline \multirow[t]{2}{*}{ Kale } & SSW & $61.1 \mathrm{a}$ & $23.6 \mathrm{~b}$ & $12.8 \mathrm{~b}$ & $102.2 \mathrm{a}$ \\
\hline & Control & $14.9 \mathrm{~b}$ & $31.6 \mathrm{a}$ & $30.1 \mathrm{a}$ & $22.7 \mathrm{~b}$ \\
\hline \multirow[t]{2}{*}{ Radish } & SSW & $54.3 \mathrm{a}$ & $36.2 \mathrm{a}$ & $12.1 \mathrm{~b}$ & $81.8 \mathrm{a}$ \\
\hline & Control & $14.0 \mathrm{~b}$ & $37.3 \mathrm{a}$ & $28.3 \mathrm{a}$ & $21.4 \mathrm{~b}$ \\
\hline \multirow[t]{2}{*}{ 'Red Crunchy' radish } & SSW & $49.5 \mathrm{a}$ & $40.4 \mathrm{a}$ & $21.0 \mathrm{~b}$ & $128.0 \mathrm{a}$ \\
\hline & Control & $6.4 \mathrm{~b}$ & $71.7 \mathrm{a}$ & $8.2 \mathrm{a}$ & $14.3 \mathrm{~b}$ \\
\hline \multirow[t]{2}{*}{ Spinach } & SSW & $55.8 \mathrm{a}$ & $54.0 \mathrm{~b}$ & $10.1 \mathrm{a}$ & $97.9 \mathrm{a}$ \\
\hline & Control & $4.4 \mathrm{~b}$ & $52.3 \mathrm{a}$ & $19.0 \mathrm{a}$ & $17.1 \mathrm{~b}$ \\
\hline Tomato & SSW & $37.3 \mathrm{a}$ & $29.4 \mathrm{~b}$ & $18.1 \mathrm{a}$ & $114.6 \mathrm{a}$ \\
\hline
\end{tabular}

${ }^{\mathrm{z}}$ For each species, means followed with same lowercase letters within each column are not significantly different between treatments by Students's $t$ test at $P<0.05$.

decreased by $47.1 \%, 35.2 \%, 65.5 \%$, and $40.3 \%$, respectively, compared with the control. The $g_{\mathrm{S}}$ was reduced for broccoli, kale, spinach, and tomato plants flooded with SSW by $81.6 \%, 51.4 \%, 76.8 \%$, and $58.1 \%$, respectively, compared with those in the control treatment. Flooding with SSW considerably affected the SPAD values of broccoli and spinach plants, but not eggplant, kale, tomato plants. Broccoli and spinach plants that were flooded with SSW had SPAD readings of $14.0 \%$ and $19.4 \%$ lesser than those in the control. Although previous studies by other researchers did not report the impact of salinity on these vegetables, gas exchange rates are reduced by salinity stress in other vegetable and agronomic crops (Niu et al., 2010; Sun et al., 2013).

Ion analysis. Leaf concentrations of $\mathrm{Na}$, $\mathrm{Cl}, \mathrm{K}$, and $\mathrm{Ca}$ were significantly different among the types of vegetables and between SSW flooding and control treatments, and the interactive effects were also significant (Table 5). SSW flooding significantly increased leaf $\mathrm{Na}$ and $\mathrm{Cl}$ concentration of all tested vegetables (Table 3). Leaf $\mathrm{Na}$ and $\mathrm{Cl}$ concentration of all plants flooded with SSW increased by $253 \%$ to $769 \%$ and $260 \%$ to $583 \%$ compared with those in the control treatment, respectively. Leaf $\mathrm{Na}$ concentration of spinach and tomato plants flooded with SSW increased the most with up to nine times higher than those in the control treatment. They also had the least loss of fresh weight ( $47 \%$ to $63 \%$ ) and DW (50\% to $58 \%$ ). However, leaf $\mathrm{Na}$ concentration of broccoli, radish, and 'Red Crunchy' radish plants that were flooded with SSW increased the least with only about three times higher than those in the control treatment. Leaf $\mathrm{Cl}$ concentration of broccoli, spinach, and tomato plants flooded with SSW increased the most up to seven times higher than those in the control treatment, whereas that of chinese cabbage and radish increased the least by only four times higher than those in the control treatment.

$\mathrm{Na}$ or $\mathrm{Cl}$ exclusion and tolerance of tissue to accumulated $\mathrm{Na}$ or $\mathrm{Cl}$ are two mechanisms of plant adaptation to salinity (Munns and Tester, 2008). However, the mechanism to exclude salts from shoots will break down and the roots become "leaky" to salts under flooded condition (Qureshi and BarrettLennard, 1998). In this study, $\mathrm{Na}$ and $\mathrm{Cl}$ ions accumulated rapidly in the leaves of 10 vegetables after they were flooded with SSW for $24 \mathrm{~h}$. The leaf $\mathrm{Na}$ and $\mathrm{Cl}$ concentrations are significantly higher than those reported previously in ornamental chili peppers irrigated with salt solution of EC of 4.1 and $8.1 \mathrm{dS} \cdot \mathrm{m}^{-1}$ (Niu et al., 2012). Most plants reported previously accumulated much less $\mathrm{Na}$ than $\mathrm{Cl}$ (Niu et al., 2010, 2012; Qureshi and Barrett-Lennard, 1998). However, in our study, less $\mathrm{Na}$ accumulated than $\mathrm{Cl}$ in the leaf tissue of all analyzed vegetables. SSW flooding might inhibit the capability of roots to screen out salt elements (Qureshi and Barrett-Lennard,
1998). The magnitude of increase in the leaf concentrations of $\mathrm{Na}$ and $\mathrm{Cl}$ varied with the types of vegetables. Leaf $\mathrm{Na}$ and $\mathrm{Cl}$ concentration of spinach and tomato plants increased the most when they were flooded with SSW. Tolerance to high $\mathrm{Na}$ and $\mathrm{Cl}$, thus, attributed to the salt tolerance of spinach and tomato plants.

Salinity can directly affect nutrient uptake, such as Na reducing $\mathrm{K}$ uptake (Akinci et al., 2004; Grattan and Grieve, 1999). In our study, leaf $\mathrm{K}$ concentrations of broccoli, chinese cabbage, eggplant, kale, spinach, and tomato decreased significantly when they were flooded with SSW (Table 5). Compared with plants in the control treatment, leaf $\mathrm{K}$ concentration in broccoli, chinese cabbage, eggplant, kale, spinach, and tomato decreased by $22.5 \%, 19.7 \%, 31.7 \%, 31.1 \%$, $24.7 \%$, and $43.8 \%$, respectively. The leaf $\mathrm{K}$ concentrations in radish and 'Red Crunchy' radish were statistically similar between treatments. Potassium plays a critical role in the turgor pressure-driven solute transport in the xylem and water balance of plants (Marschner, 1995). It is essential for plants to maintain adequate $\mathrm{K}$ levels to survive saline conditions. All these results demonstrated that $\mathrm{K}$ might be preferentially acquired and transported against a strong $\mathrm{Na}$ concentration gradient (Grattan and Grieve, 1999).

Salinity dominated by $\mathrm{Na}$ salts also reduces $\mathrm{Ca}$ availability, transport, and mobility to growing regions of the plant (Grattan and Grieve, 1999). Leaf $\mathrm{Ca}$ concentrations of broccoli, kale, radish, and 'Red Crunchy' radish decreased by $33.6 \%, 30.2 \%, 59.8 \%$, and $26.0 \%$, respectively, when they were flooded with SSW. This might be caused by depressed uptake of $\mathrm{Ca}$ from the substrate due to ion interactions, precipitation, and increases in ionic strength (Grattan and Grieve, 1999). The leaf Ca concentrations in other tested vegetables were statistically similar between treatments. Calcium plays an important role in preserving plant membrane integrity, stabilizing cell wall structures, and regulating cell wall enzyme activities (Marschner, 1995; Rengel, 1992). The decreased $\mathrm{Ca}$ availability induced by salinity would lead to severe calcium-deficiency disorders of economically important crops and further increase economic losses of vegetable production.

In conclusion, spinach, eggplant, and tomato were more tolerant to SSW flooding 
than other tested vegetables, whereas chinese cabbage, chinese greens, and cucumber were the least tolerant. Simulated seawater flooding significantly increased leaf $\mathrm{Na}$ and $\mathrm{Cl}$ concentration of all tested vegetables, but decreased leaf $\mathrm{K}$ concentrations in broccoli, chinese cabbage, eggplant, kale, spinach, and tomato and $\mathrm{Ca}$ concentrations in broccoli, kale, radish, and 'Red Crunchy' radish.

In coastal areas with intermittent seawater intrusion, crop production should consider using salt-tolerant vegetables such as spinach, eggplant, and tomato to minimize damage to the vegetables.

\section{Literature Cited}

Akinci, I.E., S. Akinci, K. Yilmaz, and H. Dikici. 2004. Response of eggplant varieties (Solanum melongena) to salinity in germination and seedling stages. N. Z. J. Crop Hort. Sci. 32:193-200.

Australian Bureau of Agricultural and Resource Economics and Sciences (ABARES). 2011. The impact of recent flood events on commodities. ABARES Special Report, Canberra, Australia.

Barrett-Lennard, E.G. 1986. Effects of waterlogging on the growth and $\mathrm{NaCl}$ uptake by vascular plants under saline condition. Reclam. Reveg. Res. 5:245-261.

Bernstein, L., L.E. Francois, and R.A. Clark. 1974. Interactive effects of salinity and fertility on yields of grains and vegetables. Agron. J. 66:412-421.

Cavins, T.J., B.E. Whipker, and W.C. Fonteno. 2008. Pourthru: A method for monitoring nutrition in the greenhouse. Acta Hort. 779:289-297.

Chartzoulakis, K. and G. Klapaki. 2000. Response of two greenhouse pepper hybrids to $\mathrm{NaCl}$ salinity during different growth stages. Sci. Hort. 86:247-260.

Ciobanu, I. and R. Sumalan. 2009. The effects of the salinity stress on the growing rates and physiological characteristics to the Lycopersicon esculentum specie. Bulletin of University of Agricultural Sciences and Veterinary Medicine Cluj-Napoca. Horticulture 66:616-620.
Ezin, V., R. De La Pena, and A. Ahanchede. 2010. Flooding tolerance of tomato genotypes during vegetative and reproductive stages. Braz. J. Plant Physiol. 22:131-142.

Gavlak, R.G., D.A. Horneck, and R.O. Miller. 1994. Plant, Soil, and Water Reference Methods for the Western Region. Western Regional Extension Publication (WREP) 125.

Grattan, S.R. and C.M. Grieve. 1999. Salinitymineral nutrient relations in horticultural crops. Sci. Hort. 78:127-157.

Huang, B., D.S. NeSmith, D.C. Bridges, and J.W Johnson. 1995a. Responses of squash to salinity, waterlogging, and subsequent drainage: I. Gas exchange, water relations, and nitrogen status. J. Plant Nutr. 18:127-140.

Huang, B., D.S. NeSmith, D.C. Bridges, and J.W. Johnson. 1995b. Responses of squash to salinity, waterlogging, and subsequent drainage: II. Root and shoot growth. J. Plant Nutr. 18:141152.

Ibrahim, K.M., D. Wright, R.B. Mirbahar, and M. Panhwar. 2007. Effects of salinity and waterlogging on ion uptake and growth of wheat varieties. Pak. J. Bot. 39:2535-2540.

Johnson, G. 2011. Salt water inundation, fresh water flooding. Weekly Crop Update, University of Delaware Cooperative Extension, Newark, DE. 16 July 2014. <http://agdev.anr.udel. edu/weeklycropupdate/?p=189>.

López-Berenguer, C., M.C. Martínez-Ballesta, C. Garcia-Viguera, and M. Carvajal. 2008. Leaf water balance mediated by aquaporins under salt stress and associated glucosinolate synthesis in broccoli. Plant Sci. 174:321-328.

Maas, E.V. 1986. Salt tolerance of plants. Appl. Agr. Res. 1:12-26.

Marschner, H. 1995. Mineral nutrition of higher plants. 2nd ed. Academic Press, London, UK.

Munns, R. and M. Tester. 2008. Mechanisms of salinity tolerance. Annu. Rev. Plant Biol. 59:651-681.

Niu, G., D.S. Rodriguez, E. Call, P.W. Bosland, A. Ulery, and E. Acosta. 2010. Responses of eight chile peppers to saline water irrigation. Sci. Hort. 126:215-222.

Niu, G., P. Osuna, Y.P. Sun, and D. Rodriguez. 2012. Seedling emergence, growth, and mineral nutrition of ornamental chili peppers irrigated with saline water. HortScience 47:1653-1657.

Qureshi, R.H. and E.G. Barrett-Lennard. 1998. Saline agriculture for irrigated land in Pakistan: A handbook. Australian Center for International Agricultural Research, Canberra, Australia.

Rengel, Z. 1992. The role of calcium in salt toxicity. Plant Cell Environ. 15:625-632.

Savvas, D. and F. Lenz. 1996. Influence of $\mathrm{NaCl}$ concentration in the nutrient solution on mineral composition of eggplants grown in sand culture. Angewandte Botanik 70:124-127.

Shalhevet, J., B. Heuer, and A. Meiri. 1983. Irrigation interval as a factor in the salt tolerance of eggplant. Irrig. Sci. 4:83-93.

Shannon, M.C. and C.M. Grieve. 1999. Tolerance of vegetable crops to salinity. Sci. Hort. 78:5-38.

Staff, USDA. 1954. Diagnosis and improvement of saline and alkaline soils, p. 7-16. In: Richards, L.A. (ed.). USDA Agriculture handbook no. 60. U.S. Government Printing Office, Washington, DC.

Stoner, R. 1988. Engineering a solution to the problem of salt-laden soils. New Sci. 120:44.

Sun, Y., G. Niu, P. Osuna, G. Ganjegunte, D. Auld, L. Zhao, J.R. Peralta-Videa, and J.L. GardeaTorresdey. 2013. Seedling emergence, growth, and leaf mineral nutrition of Ricinus communis L. cultivars irrigated with saline solution. Ind. Crops Prod. 49:75-80.

Ungar, I.A. 1996. Influence of salinity on seed germination in succulent halophytes. Ecology 43:191-201.

Ünlükara, A., A. Kurunc, G.D. Kesmez, E. Yurtseven, and D.L. Suarez. 2010. Effects of salinity on eggplant (Solanum melongena L.) growth and evapotranspiration. Irrig. Drain. 59:203-214.

Visser, E.J.W., L.A.C.J. Voesenek, B.B. Vartapetian, and M.B. Jackson. 2003. Flooding and plant growth. Ann. Bot. (Lond.) 91:107-109.

Wikipedia. The Free Encyclopedia. 2014. Seawater. Wikimedia foundation, Inc., San Francisco, CA. 16 July 2014. <http://en.wikipedia.org/ wiki/Hydrangea $>$.

Yamaguchi, T. and E. Blumwald. 2005. Developing salt-tolerant crop plants: Challenges and opportunities. Trends Plant Sci. 10:616-619. 